REDESCRIPTION OF TYPES OF AMERICAN MUSCOID FLIES IN THE COLLECTION OF THE VIENNA NATURAL HISTORY MUSEUM, WITH INCIDENTAL NOTES

\author{
By J. M. AldRICH \\ Associate Curator, Division of Insects, United States National Museum
}

The Vienna Natural History Museum contains a large amount of type material in the American muscoid flies. This is principally in the species described by Wiedemann ${ }^{1}$ in 1830 , by Schiner $^{2}$ in 1868 , and by Brauer and Bergenstamm ${ }^{3}$ in parts 4,5 , and 6 of their series called "Zweiflügler des Kaiserlichen Museums zu Wien." The last-named series contains many new genera based on new species and those of Wiedemann and Schiner.

The authorities of the Vienna Museum a few years ago indicated a willingness to lend the American types to this museum for study, and I have availed myself of their liberality so far as to borrow six lots, numbering in all 110 species. I have reported on 79 of these in three articles published in the Annals of the Entomological Society of America. ${ }^{4}$ On account of the magnitude of the project it is thought best to continue it in the Proceedings of the Museum, and the remainder thus far studied are included in the present paper.

The study of these types has verified many identifications in the United States National Museum, demonstrated the synonomy of many genera and species, and furnished more complete data than formerly existed for the future identification of a considerable number of species not as yet represented in this museum.

1 Aussereuropäische Zweiflügelige Insekten, 2 volumes.

2 Diptera der Novara Reise, 1 volume.

${ }^{3}$.Denkschriften der Kaiserlichen Akademie der Wissenschaften; part 4 is in vol. 56, 1889 , pp. $1-180$, with 11 plates; part 5 in vol. 58, 1891, pp. 305-446; and part 6 in vol. $60,1893, \mathrm{pp} .89-240$.

Vol. 17, 1924, pp. 209-218; vol. 18, 1925, pp. 107-130 and 456-469.

No. 2703.-PRoceedings U. S. NATIONAL Museum, Vol. 72 , ARt. 7 $55415-27-1$ 
The species reported upon in the three articles just mentioned are as follows:

FIRST PAPER

1. Morellia bipuncta Wiedemann.

2. Sarcophaga plinthopyga Wiedemann.

3. Sarcophaga georgina Wiedemann.

4. Sarcophaga chrysostoma Wiedemann.

5. Sarcophaga rufiventris Wiedemann.

6. Erythrandra picipes Brauer and Bergenstamm.

7. Arrenopus americanus Brauer and Bergenstamm.

8. Megaprosopus rufiventris Macquart.

9. Macrometopa mexicana Brauer and Bergenstamm.

10. Prorhynchops bilimeki Brauer and Bergenstamm.

11. Eudexia gotiath Brauer and Bergenstamm.

12. Echinodexia pseudohystricia Brauer and Bergenstamm.

13. Myiophasia aenea Wiedemann.

14. Angiorhina crudelis Wiedemann.

15. Oestrophasia clausa Brauer and Bergenstamm.

16. Phasiopteryx bilimeki Brauer and Bergenstamm.

17. Tetragrapha tessellata Brauer and Bergenstamm.

18. Podotachina vibrissata Brauer and Bergenstamm.

19. Podotachina americana Brauer and Bergenstamm.

20. Parahypochaeta heteroneura Brauer and Bergenstamm.

21. Plagiomima disparata Brauer and Bergenstamm.

22. Myiopharus metopia Brauer and Bergenstamm.

23. Hesperomyia erythrocera Brauer and Bergenstamm.

24. Hemithrixion oestriforme Brauer and Bergenstamm

25. Pseudogermaria georgiae Brauer and Bergenstamm.

26. Eliozeta americana Brauer and Bergenstamm.

\section{SECOND PAPER}

27. Viviania georgiae Brauer and Bergenstamm.

28. Masiphya brasiliana Brauer and Bergenstamm.

29. Alsopsyche nemoralis Brauer and Bergenstamm.

30. Chrysotachina rheinwardtii Wiedemann.

31. Nemorilla trivittata Wiedemann.

32. Prospalaea insularis Brauer and Bergenstamm.

33. Gaediopsis mexicana Brauer and Bergenstamm.

34. Paralispe brasiliana Brauer and Bergenstamm.

35. Sardiocera valida Brauer and Bergenstamm.

36. Gonia rubens Wiedemann.

37. Ptilodexia carolinensis Brauer and Bergenstamm.

38. Trichodura anceps Fabricius.

39. Chaetogyne vexans Wiedemann.

40. Mochlosoma validum Brauer and Bergenstamm.

41. Lasiopalpus flavitarsis Macquart.

42. Myiomitho elata Brauer and Lergensiamm.

43. Pseudoredtenbacheria brasilicnsis Srhiner.

44. Beskia cornuta Braner and liergenstamm.

45. Peteina stylata lirauer and liergenstamm

46. Wulpia aperta Erauer and Bergenstamm. 
47. Leskiomima tenera Wiedemann.

48. Microchira mexicana Brauer and Bergenstamm.

49. Argyromima mirabilis Brauer and Bergenstamm.

50. Leptoda gracilis Wiedemann.

51. Myiomima sarcophagina Brauer and Bergenstamm.

52. Tropiopsis pyrrhaspis Wiedemann.

53. Leptoda thomae Wiedemann.

54. Bibiomima handlirschi Brauer and Bergenstamm.

55. Reinwardtia tachinina Brauer and Bergenstamm.

56. Masipoda geminata Brauer and Bergenstamm.

57. Sturmia cubaecola Jaennicke.

58. Argyrophylax albincisa Wiedemann.

59. Trichophora analis Schiner.

60. Arthrochaeta demoticoides Brauer and Bergenstamm

THIRD PAPER

61. Paralucilia fulvipes Blanchard.

62. Paradoria nigra Brauer and Bergenstamm.

63. Paragymnomma hystrix Brauer and Bergenstamm.

64. Bombyliomyia flavipalpis Macquart.

65. Phasiophana obsoleta Brauer and Bergenstamm.

66. Cryptomeigenia setifacies Brauer and Bergenstamm.

67. Pseudoviviania platypoda Brauer and Bergenstamm.

68. Selenomyia brevicornis Brauer and Bergenstamm.

69. Sisyropa vorax Wiedemann.

70. Chaetoprocta tarsalis Schiner.

71. Thysanomyia fimbriata Van der Wulp.

72. Macromeigenia chrysoprocta Wiedemann.

73. Gaediophana atra Brauer and Bergenstamm.

74. Paragaedia hedemanni Brauer and Bergenstamm.

75. Hypotachina disparata Brauer and Bergenstamm.

76. Exorista optica Schiner.

77. Mallonotum brevicornis Wiedemann.

78. Parexorista inculta Wiedemann.

79. Tricholyga vivida Wiedemann.

The species in the present paper are numbered consecutively with the preceding.

80. ACTINOCHAETA COLUMBIAE Brauer and Bergenstamm

Actinochaeta columbiae Brauer and Bergenstamm, Denk. Wien. Akad. Wiss., vol. 56, 1899, p. 137 ; vol. 58, 1893, p. 128.

Two females, both "Lindig 1864 Venezuela" and both with label in purple ink, large hand, "columbiae BB type."

These agree with the description and may be the types although originally the species was said to be from (iolombia. An easily recognizable species with outstanding characters, among them the front tarsi greatly enlarged and lengthenerl; the scutellum with only two pairs of bristles, apical strongly decussate; ablomen much compressed, without discals; postscutellum and hypopleural bristles dis. 
tinct; first, third, and fifth veins hairy; no acrostichals; facial ridges with fine hairs.

Townsend had identified the species correctly from Panama and Peru in the United States National Museum. I afterwards found a specimen in the collection from Costa Rica. The type and our three specimens are all females.

\section{PACHYGRAPHIA VIRGATA Wiedemann}

Dexia virgata WiedemanN, Auss. Zweifl., vol. 2, 1830, p. 382.

Pachygraphia virgata Brauer and Bergenstamm, Denk. Wien. Akad. Wiss., vol. 58,1891 , p. 406 , vol. 60,1893 , p. 132 -Townsend, Ins. Ins. Menst., vol. 4,1916, p. 8.

Brauer and Bergenstamm in both references included Dexia virgata Wiedemann and Dexia fervens Wiedemann under Pachygraphia. Townsend designated the former as type of this genus.

One female "Brasilien" labeled with genus and species but not the word "type"; an old specimen with no legs, very few bristles and only one third antennal joint; thorax in bad condition and abdomen roughly glued on. It is possible to ascertain immediately that my genus Camptops ${ }^{5}$ is a synonym of Pachygraphia. The shape of the head in virgata is exactly like that of unicolor, genotype of Camptops. They agree in having one orbital bristle, the vibrissae above the lower edge of the head, and so forth, but virgata has quite black palpi as mentioned by Wiedemann. In unicolor there is a blackish changeable spot in the pollen of the upper part of the parafacial between the second antennal joint and the eye, which is entirely absent in virgata. The plumosity of the arista is longer in virgata and seems to continue to the extreme tip. The parafacial has a few small hairs, not in rows, just about as in unicolor. The only difference I can make out in the chaetotaxy is that virgata has two intraalars, of which the anterior is absent in unicolor. In both there is no postscutellum, the third vein has six widely separated setules reaching nearly to the cross vein; bend of fourth vein rectangular with short stump, last section of fifth vein shorter than hind cross vein. In virgata the first posterior cell is narrowly open a little before the tip.

The species is not represented in the National Museum.

\section{2. ? PACHYGRAPHIA FERVENS Wiedemann}

Dexia fervens Wiedemann, Auss. Zweifl., vol. 2, 1830, p. 383.

Pachygraphia fervens Brauer and Bergenstamm, Denk. Wien. Akad. Wiss., vol. 58, 1891, p. 406 ; vol. 60, 1893, p. 132.

One male, labeled "Brasilien," "fervens W. Coll. Winthem," and "Pachygraphia fervens Wd." It does not bear the word type, but

\footnotetext{
- Sarcophaga and Allies, 1916, p. 34.
} 
agrees with Wiedemann's description in regard to the peculiar sealbrown median abdominal stripe, so I do not doubt that this is the type of the species. It does not belong to Pachygraphia (type virgata Wiedemann) already mentioned, but being in poor condition I will not attempt to establish a new genus upon this specimen. The best that I can do is to mention characters sufficient to identify the species when new material is obtained.

It is a rather slender, gray fly, nearly $6 \mathrm{~mm}$. long, with a very striking seal-brown stripe on the last three abdominal segments, occupying about one-third of their width. Apparently a similar stripe exists on the thorax, since I can make it out on the scritellum and just before. The remainder of the abdomen is densely yellowish pollinose above; no median marginals on first and second segments; if any are present on the latter they must be very small; third with a marginal row of 6 ; the fourth has a marginal row of 6 ; and the fifth has a marginal row of the same number, but no discals whatever. In the specimen the abdomen is rather flattened and has a sharp margin on each side which seems to be correlated with the color pattern but may be an individual peculiarity. There are only two sternopleurals; no pteropleural; well-developed row of hypopleural; only two pairs of scutellar. No trace of postscutellum. The wings narrow, third vein with two minute hairs at base; fourth vein with angular bend which is rather close to hind margin, ending not very far before tip of wing; last section of fifth vein about oneseventh of the preceding. Head considerably shriveled, the front moderately narrow, apparently without ocellars; frontals extending slightly beyond base of antennae; parafacial rather narrow and apparently bare, the deeply shriveled facial ridges bare; vibrissae at oral margin; third antennal joint narrow, about twice the second, which is swollen toward the tip; arista pollinose to the tip, its extreme base enlarged. Palpi and proboscis rather small. Legs black, middle tibia with no bristles on outer front side; hind tibia with one on outer and one on inner hind side at the middle and one above the latter halfway to the base; also one on outer flexor side below middle.

The species is not represented in the National Museum nor in any other collections that I have seen.

\section{CHAETODEMOTICUS CHILENSIS Schiner}

Demoticus chitensis ScHINER, Novara, 1868, p. 324.

Chaetodemoticus chilensis Brauer and Bergenstamm, Denk. Wien. Akad. Wiss., vol. 58, 1891, p. 385 ; vol. 60, 1893, p. 140.

One male, "Novara-R. Chili," labeled as type of species, which is the type of the genus. Eyes bare, front broad, 0.42 of the head width at vertex, which is not much narrower than the space between the eyes at the vibrissae; two large verticals, the inner especially strong; ocellars stout, divergent and reclinate; frontals about 11 , 
the uppermost strongly divergent and reclinate, those below convergent, the lowest two or three extending down on the face and proclinate, the uppermost one of these being at the level of the base of the third antennal joint. About four pairs of proclinate orbital bristles present, the uppermost small and close to the divergent frontals, the lowest opposite insertion of antennae nearly in line with the proclinate frontals. Parafrontal narrow above, the median stripe very wide; just above the antennae however the stripe is only as wide as one parafrontal. Parafacial moderately wide with numerous smallish black hairs. Cheek about one-fourth the eye height, bare except below and posteriorly. Mouth a little protuberant so that the length of the head here is equal to that at the insertion of the antennae. Facial ridges bare, face flat transversely. Vibrissae at the oral margin arising from a cluster of smaller bristles; antennae fully three-fourths as long as face; second antennal joint about two-thirds as long as the third; arista short, thickened nearly to the tip, the basal joints short. Palpi normal; proboscis short, but quite slender beyond the joint. Back of head a little bulging, with only white hair except the orbital row and a few dark hairs near the mouth. Thoracic chaetotaxy : acrostichal, $3,3(?)$; dorsocentral, 3 , 4 ; humeral, 4 ; posthumeral, 2 ; presutural, 2 ; notopleural, 2 ; supraalar, 3 (the middle large) ; intraalar, 2 ; postalar, 2 ; sternopleural, 2,1 ; pteropleural, 0 ; scutellum with three marginal, no apical, but scars indicating 2 pairs of bristles irregularly placed just above the apex.

Abdomen rather thick toward apex, no median marginals on first segment, second with one pair but no discals, third with a marginal row of about 10, no discals; fourth with a marginal row smaller and a subdiscal row about at the last third. Legs black, rather stout and bristly; pulvilli moderately elongated; middle tibia with three or four stout bristles on outer front side, hind tibia with irregular and unequal bristles on outer hind side and inner hind side.

Wing subhyaline, first posterior cell ending far before the apex, first vein with coarse hairs to the tip, third vein with similar hairs extending beyond the cross vein; bend of fourth vein angular and slightly appendiculate; last section of fifth vein about one-third the preceding.

General color dark gray, the head subsilvery; palpi and second antennal joint reddish-yellow; stripes of mesonotum considerably lamaged in the specimen but apparently not distinct. Abdomen bluish-gray on second and third segments, not tessellated, the hind margins shining black, fourth segment almost entirely shining black. Genitalia rather large, concealed in the specimen.

Length, $9 \mathrm{~mm}$.

Not represented in the National Museum. 


\section{RHINOMACQUARTIA CHAETOPHORA Brauer and Bergenstamm}

Rhinomacquartia chaetophora Brauer and Bergenstamm, Denk. Wien. Akad. Wiss., vol. 58, 1891, pp. 373, 380, 404 ; vol. 60, 1893, p. 134.

One female, the type, collected by Natterer at Ypanema, Brazil, and so labeled in abbreviated form. The species is so remarkable that it can not be placed in very close association with any known to me. Brauer and Bergenstamm in 1891 placed it first in Group Pseudodexiidae. Within this group however they have several subdivisions to which they give the family ending, and they recognize Rhinomacquartiidae for this sole species on page 380 ; but on page 404 they have "subgroup Rhinomacquartia" consisting of this genus with a few others doubtfully added. In 1893, they divide "Sectio Pseudodexiidae" into 17 subsections one of which is Rhinomacquartia, containing only this single genus and species. As their "Group Pseudodexiidae" is very heterogeneous, they in effect indicate no close relatives of the present genus. They were puzzled as to the sex of the specimen; the somewhat distorted apex of the abdomen did not seem to show male characters, but the front had no orbitals, so they put it down as a male with an interrogation. I relaxed the specimen and examined the abdominal structure and find it a female. The hypopleural bristles and postscutellum are well developed (I examined the latter while the specimen was relaxed). The arista is plumose above, below and in several other planes; it is hardly longer than the third antennal joint, and curved downward. The eyes are densely hairy. The head is flat behind and elongated forward, the length at antenna and epistoma are the same; this makes the parafacial unusually wide; it is nearly covered with uniform fine hair gradually becoming longer below. The front is quite prominent, broad, apparently without orbitals; ocellars broken off, outer vertical hairlike; the frontals very small above, the row ending at antennal insertion. On one side there is a scar on the parafrontal a little in advance of the anterior ocellus while on the opposite side the corresponding scar is considerably farther forward. Whether these represent a pair of reclinate verticals or a pair of orbitals I can not tell. Epistoma strongly thrust forward between the vibrissae, the face concave in profile, ridges bare. Proboscis short, fleshy, palpi normal. Third antennal joint with parallel sides, rather elongate, more than twice the second; basal joints of arista small. Micrometer measurements of the head are as follows: width, 55 units; length at antennae, 38, at epistoma the same; height, 48 (eye, 33, cheek, 15); vertex, 16 (or 0.29 of head width).

Thoracic chaetotaxy: acrostichal 3 anterior, posterior doubtful; dorsocentral, 3, 4 (the second posterior small and irregularly placed); humeral, 4; posthumeral, 2 (the hind one small); presutural, 1; notopleural, 2 ; supraalar, 3 ; intraalar, 2 ; postalar, 2 ; sternopleural, 
2, 1; pteropleural, 0 ; scutellum with 2 lateral, 1 discal, scars of minute apical pair; prosternum bare. Hind calypter of good size, bare, a group of minute setules beneath it.

Abdomen ovate, with weak bristles; none on first segment, second with weak marginal pair, no discals; third with marginal row of 6 rather strong and some irregular bristly discal hairs; fourth segment with marginal row and a few small irregular on disk. Basal sternite visible, the others covered. Middle legs missing, hind tibia with very sparse and irregular cilia.

Wing subhyaline, fourth vein a little curved backward, the bend rounded and rather close to hind margin; first posterior cell open only slightly before extreme apex; third vein with $3-5$ setules at base, all the other veins bare, including stem vein. No costal spine. Hind cross vein nearly three-fourths of the way from small cross vein to bend of fourth.

Head yellow, only the upper two-thirds of back, vertex, arista, and third antennal joint except base, black; cheeks with pale yellow hair, the bristles of epistoma beginning at about the middle. Thorax black, rather uniformly cinereous pollinose, scutellum concolorous.

Abdomen yellow with median black stripe as wide as the distance between the two largest scutellar bristles; this stripe widens on posterior half of second segment into a flat triangle almost reaching the sides; on the third segment it forms a larger triangle covering all but the outer front part; fourth segment wholly black above except narrow margins. Venter yellow with some brownish stains.

Legs yellow except tarsi, which are black.

Length, $9 \mathrm{~mm}$.

I can find no near relative in the United States National Museum, but I venture to suggest Booponus intonsus Aldrich as having some similar characters, including bare prosternum.

\section{ACHAETONEURA LATA Wiedemann}

Tachina lata Wiedemann, Auss. Zweifl., vol. 2, 1830, p. 322.

Achaetoneura lata Brauer and Bergenstamm, Denk. Wien. Akad. Wiss., vol. 58, 1891, 334.

One female, labeled "lata Wd. Coll. Winthem," and "lata Wd., Montevideo." Although Wiedemann stated that the type was in his own collection, Brauer at the very beginning of the series entitled "Zweiflügler des Kaiserlichen Museums" has explained that many of the types were in some way transferred from Wiedemann's to Winthem's collection. There is no reason to doubt that this specimen is the type of lata, although there are slight discrepancies in both existing descriptions. 
Female-Length, $9 \mathrm{~mm}$. Eyes slightly but perceptibly hairy. Front broad, 0.37 of head width at the vertex, gradually widening as the face also does to lower curve of eye. Pollen of parafrontals, parafacials, and posterior orbit light golden yellow, which, however, does not extend upon the cheek. Middle of face cinereous, the ridges darker and bristly halfway (one side) or more (the other side); cheek one-third of eye height, hairy; proboscis short, fleshy; palpi of usual size, yellow, tips a little swollen. Antennae black, base of third joint reddish; third joint three times the second (not four, as stated by Brauer and Bergenstamm), rather thick at base and distinctly tapering to a small apex; arista bare, its penultimate joint short, thickened to middle. Frontal bristles damaged, only the scars left of many; the usual orbitals are indicated, one ocellar remains, but twisted (?) toward the side. Back of head with white beard, bushy below. Thorax black with bluish-gray pollen; the usual four stripes visible from behind, somewhat coalescing behind suture. Scutellum slightly reddish at tip. Anterior acrostichal 3 on one side, 2 on the other (lacking the one just before the suture on this side). Scutellum with three large lateral, the apical (scars) far apart and strong; one discal scutellar pair. Supraalar 2; sternopleural 1, 1 on one side, the other 2, 1, but the lower small. Abdomen with nearly uniform bluish-gray pollen, becoming distinctly more yellowish on fourth segment; the hair is coarse and almost suberect. First segment with one pair median marginals; second with one pair; third with a marginal row of about 10, and a submarginal irregular pair on the middle, too far back to be called discals; fourth segment with numerous erect small and large bristles beginning near base. In spite of Weidemann's statement, the abdomen shows very little tessellation. Legs black; middle tibia with two bristles on outer front side, the lower large; hind tibia with a row of erect almost uniform bristles on the whole length, just below the middle one considerably larger (on one side, the other has two less enlarged at this place). This does not quite agree with Brauer and Bergenstamm. Wing subhyaline, third vein with two small setules at base; fourth vein with oblique rounded bend, ending considerably before apex.

The species is exceedingly like Frontina frenchii Williston (synonym hesperus Brauer and Bergenstamm, type of Achaetoneura) of the United States, but the latter has bare eyes, four sternopleurcii, three supraalars, and the thira antennal joint is broad to the tip.

Not represented in the National Museum. 


\section{MICROCHIRA APERTA Brauer and Bergenstamm}

Paradidyma aperta Brauer and Bergenstamm, Denk. Wien. Akad. Wiss., vol. 60,1893, p. 127.

Microchira mexicana Brauer and Bergenstamm, Denk. Wien. Akad. Wiss., vol. 60,1893 , p. 128.-AldRICH, Annals Ent. Soc. Amer., vol. 18, 1925, p. 121.

One male labeled "Bilimek, Mexico, 1883," undoubted type of the species. This is clearly the male of Microchira mexicana, described by Brauer and Bergenstamm on the following page from a female; I have previously reported on this specimen as indicated above. The male differs from the female principally in the shape of the head, having a narrower and much more prominent front and stouter antennae. The frontals extend in an irregular row down the parafacial to the transverse impression, about to the lower curve of the eye, and are considerably larger and more numerous than in the female; the hairs of the upper parafacial and lower part of parafrontal are coarse and bristly. The third antennal joint is considerably stouter than in the female and nearly four times the second. The arista is thickened on the basal two-fifths and distinctly pubescent. As in the female, the pollen of the head, thorax, and abdomen has a somewhat yellowish cast, especially on the lower part of the head and the last abdominal segment. The male differs from the female in having normal front tarsi with moderately elongated claws and pulvilli.

The National Museum contains two females of aperta from Federal District, Mexico, collected by E. G. Smyth on August 31, 1922.

\section{HYSTRICIA COPULATA Wiedemann}

Tachina copulata Wiedemann, Auss. Zweifl., vol. 2, 1830, p. 295.

Hystricia copulata Brauge and Bergenstamm, Denk. Wien. Akad. Wiss.s vol. 58, 1891, p. 409.-ENGEL, Zool. Jahrb., vol. 43, 1920, p. 306, fig.

The history of this species is very curious. Wiedemann described it from two Brazilian specimens which he evidently believed had been taken in copulation. He noted that the male had a dark face and blackish beard, while the female had a yellowish face and white beard. Both specimens are before me. His male bears a very old label, probably Wiedemann's, in ink brown with age, "copulata Wied. ô Brasilien," also a Brauer and Bergenstamm label, "Hystricia copulata Wied.," and a red label, "Type." The other specimen, also a male, is labeled "cop. $\&$ " in the same handwriting and brown ink as the preceding; also "Brasilien" a Brauer and Bergenstamm label "Willistonia copulata Wied.," and "Coll. Winthem." 
Brauer and Bergenstamm, 1891, in their systematic list of the material in the Vienna Museum, entered Willistonia copulata Wiedemann on page 403, and Hystricia copulata Wiedemann on page 409, but gave no indication that these were described as a single species by Wiedemann.

The supposed female is a male of a species of Belvosia. It lacks the fourth abdominal tergite almost completely, which greatly changes its appearance and misled Wiedemann. There are only one or two narrow vestiges of this tergite present, but they show characteristic dense white pollen; the fifth sternite is present and indicates the male sex, as the absence of fronto-orbitals also does.

The male (to which the species is hereby restricted) has been reported upon in detail and the genitalia well figured by Engel. $\mathrm{He}$ follows Brauer and Bergenstamm in placing it in the genus Hystricia, and $I$ agree in this. On looking for the species in the National Museum, I found only a single female, which Townsend had placed under a manuscript specific name in his genus Hystriciopsis. This genus was proposed by Townsend ${ }^{6}$ for the new species obscura, from Peru; the characters were as follows: "Runs to Hystricia in Brauer and Bergenstamm's tables. May be distinguished by the epistoma being only moderately salient, not nasute; by the thickly haired tegulae, and by the distinctly curvate character of the spinelike macrochaetae." On comparing obscura with amoena Macquart, the genotype of Hystricia, I find they are just alike in the pilosity of the calypter, while the other characters adduced seem too slight to establish a genus upon. Hystricia has, among other characters, bare parafacials, pilose eyes, palpi of good size but not excessively developed, lower calypter hairy, with numerous spinose bristles on scutellum and 2-4 abdominal tergites, also a few on the sternites.

Hystricia copulata is a smaller species than amoena and obscura. The pollen of the male is spoiled, but in the female in the National Museum it is slate colored on the parafrontals, pale plumbeous on parafacials, face and cheeks; the palpi are almost black, only the tips a little paler; anterior part of thorax with considerable cinereous pollen, becoming thinner toward scutellum, which is shining brown. Calypters dark brown with dense blackish hair. The abdomen is shining brown with some indications of reddish, and in a very oblique view a slight trace of brown pollen. Venter wholly shining. The narrowest part of the front is 0.15 of head width in male, and 0.22 in female. The cheek is about 0.4 the eye height in both sexes: the beard white behind but considerably mixed with black on upper and anterior part of cheek; several rather distinct bristles stand a

- Ins. Ins. Menst., vol. 2, 1914, p. 85. 
little outside the vibrissae, separated by a reddish downward prolongation of the transverse impression. Engel's description and figure supply sufficient details.

I leave Wiedemann's supposed female, really a male of Betvosia, without further identification, as it is in poor condition.

\section{ZENILLIA THERMOPHILA Wiedemann}

Tachina thermophila Wiedemann, Auss. Zweifl., vol. 2, 1830, p. 325.

Sisyropa thermophila Brauer and Bergenstamm, Denk. Wien. Akad. Wiss., vol. 56, 1889, p. 163 ; vol. 58, 1891, p. 344 ; vol. 60,1893 , p. 113, 122.

One male, "thermophila Wied. Java," and "Coll. Winthem," also red "type" label. I asked to see this Java specimen in order to assure myself about the status of the genus Sisyropa, this being the type species.

The genus was established by Brauer and Bergenstamm in 1889 (p. 163), with only this species. In 1891 (p. 344), the authors gave a synopsis of a dozen species, from Java, Europe, Australia, and Brazil, prefacing with the remark, "We should probably have done better to unite the species of this genus with those in the genus Parexorista, with which, as also with Chaetolyga, they have the head structure in common." In 1893, however, they place Sisyropa in the section Blepharipoda (p. 122), and Parexorista in section Masicera (p. 113).

Since the standing of the genus depends entirely (aside from questions of priority) upon the characters of the type species, these will be briefly enumerated. The head of the specimen is obviously shrunken, so micrometer measurements are of doubtful value.

Male, front moderately wide, face considerably wider but not widening very much below middle; front not prominent, face moderately receding; cheek probably about one-sixth the eye height in normal specimen; parafacial bare, very narrow below; vibrissae at oral margin; clypeus wide, facial ridges bristly only one-fifth of the way. Ocellars small, proclinate, parallel; frontals about 10, the uppermost pair large and reclinate, succeeding ones small, then gradually larger near antennae, the lowest almost at level of arista; one or two smallish bristles outside the main frontal row near antennal insertion. Antennae reaching four-fifths of the way to the oral margin, third joint of medium width, a little more than twice the second; arista slender, only a little thickened on proximal half, basal joints short. Palpi normal, proboscis short, fleshy.

Thoracic chaetotaxy: acrostichal, 3, 3 (damaged, a little uncertain) ; dorsocentral, 2, 4; humeral, 3 ; posthumeral, 2 ; presutural, 2 ; notopleural, 2 ; supraalar, 3 ; intraalar, 3 ; postalar, 2 ; sternopleural, 2, 1; pteropleural minute; scutellum with 4 lateral, 1 rather large depressed apical, 1 discal. 
Abdomen ovate; first and second segments with one smallish erect median marginal pair of bristles, third with a marginal row of about 12 larger; fourth with erect coarse hairs becoming bristly at hind margin; no discals on second and third, but the hairs on whole dorsal surface are rather dense, evenly placed, and become more erect near the median line. On the venter of the third segment, the inflexed tergite bears on each side a distinct rounded tuft of long hairs.

The legs are of ordinary structure, the claws and pulvilli moderately elongated; middle tibia with two bristles on outer front side and a smaller depressed one below them. The hind tibiae are obviously ciliated, with one bristle below middle row.

Wings ordinary; first posterior cell rather wide open well before tip of wing; third vein with three or four setules at base, the others bare.

The species is not represented in the National Museum. The North American species Zenillia eudryae Townsend shows hardly a single difference throughout; three instead of four lateral scutellar bristles is the only one I find. Carcelia gnava Meigen of Europe is also closely related, and as the genus Carcelia dates from 1830 it certainly includes Sisyropa as a synonym. Townsend based his genue Oxexorista on eudryae, but later restricted the genotype to a single specimen which he named thompsoni. ${ }^{7}$. This specimen shows only slight differences from eudryae, hence Oxexorista also becomes a synonym of Carcetia. It was the judgment of Aldrich and Webber ${ }^{8}$ that Carcelia itself should be a synonym of Zenillia Robineau-Desvoidy.

\section{ZENILLIA RUFIVENTRIS Brauer and Bergenstamm}

Sisyropa rufiventris Brauer and Bergenstamm, Denk. Wien. Akad. Wiss., vol. 58,1891 , p. 346.

One male, "Beske, Brasilien," with Brauer and Bergenstamm label. Undoubted type. This goes readily in Exorista of authors (for which Zenillia is used by Aldrich and Webber). Not in National Museum. It is closely allied to cheloniae Rondani, and hence may be referred to the subgenus Parexorista. There is no outer vertical bristle. The body surface and chaetotaxy are considerably damaged, although the head is perfect. Front 0.24 of head width by micrometer. The apical half of the fourth abdominal segment is shining black, apparently contrasting with basal half. Most of the dorsum of the abdomen and nearly all the venter red. Middle tibia with one bristle on outer front side.

\footnotetext{
${ }^{7}$ Proc. Ent. Soc. Wiash., rol. 14, 1912, p. 16i; ; and l'roc. Liol. Soc. Wash., vol. 28, 1915. p. 21.

${ }^{8}$ Proc. U. S. Sat. Yfus., vol. C3, art. 17, 192, , p. i.
} 
90. ZENILLIA PROSPERINA Brauer and Bergenstamm

Sisyropa proserpina Brauer and Bergenstamm, Denk. Wien. Akad. Wiss., vol. 58,1891, p. 347 .

One male, "Brasilien," with Brauer and Bergenstamm label. The undoubted type. The species has been described by Brauer and Bergenstamm and shows few noteworthy additional characters. It is a large robust form, which would readily go in Exorista of authors (Zenillia as used by Aldrich and Webber). Palpi dark yellow, covered with dense black hairs; dorsocentral 3, 4; presutural 2; sternopleural 2, 1; scutellum with 3 lateral, 1 apical decussate and depressed; pteropleural minute. No discals on second and third abdominal segments, on which the dark pattern takes the form of a broad median stripe and a lateral triangle, which is contiguous and does not reach the front edge. The third tergite has no cluster of hairs below. Middle tibia with one bristle on outer front side; hind tibia ciliate; tarsi with long claws and pulvilli.

The species is not in the National Museum.

\section{WINTHEMIA XANTHOCERA Wiedemann}

Tachina xanthocera WiEdemanN, Auss. Zweifl., vol. 2, 1830, p. 329.

Masipoda xanthocera Brauer and Bergenstamm, Denk. Wien. Akad. Wiss., vol. 56,1889 , p. 163 ; vol. 58, 1891, p. 402 ; vol. 60 , 1893, p. 123.

One female, "Brasilien"; an old folded label reads "xanthocera Wied. Coll. Winthem." Agrees with description except that the front is cinereous pollinose with dark red stripe, and the antennae are more reddish-brown than reddish-yellow. I believe it is one of the type series, of which Wiedemann had at least two. It is a true Winthemia (syn. Masipoda), in spite of the fact that even under a high power it shows not a single parafacial hair. Otherwise it has the characteristic structure of the genus throughout, including the tubular ovipositor. The second abdominal segment has a single large pair of marginals; the middle tibia has a single bristle on the outer front side near middle; there are only two sternopleurals.

One female in the National Museum, collected at Bartica, British Guiana, June 7, 1901, agrees remarkably throughout except that under a high power it shows two or three pale slender hairs on the parafacial. Provisionally I regard this as the same species. Only the discovery of the male can clear the species up any further.

\section{URAMYIA PRODUCTA Robineau-Desvoidy}

Uramyia producta RoBINeAU-DesvoIDY, Myodaires, 1830, p. 204.-BraUer and Bergenstamm, Denk. Wien. Akad. Wiss., vol. 58, 1891, p. 130 ; vol. 60, 1893 , p. 135.

Two males; one labeled "Schott Brasilien," the other "Bahia Coll. Winthem." 
These are not types, but the species is the type of Uramyia. The specimens agree exactly with those identified by Townsend in the National Museum, and discussed by me. ${ }^{9}$

\section{GYMNOSTYLIA Macquart}

The status of this genus requires elucidation before proceeding to a discussion of the three species received under this generic name.

Macquart described the genus in his Histoire Naturelle de Diptères. ${ }^{10} \mathrm{He}$ included three species from Robineau's Myodaires of 1830-Macromya depressa, Harrisia scutellaris, and in a separate division with tomentose arista Leschenaultia cilipes. These were all Brazilian species. No genotype was indicated until 1916, when Townsend ${ }^{11}$ designated Macromya depressa. On the same page he designated the same species as genotype of Macromya RobineauDesvoidy ${ }^{12}$ which originally contained this and one other Brazilian species. Thus Gymnostylia is a complete synonym of Macromya. The genotype of the latter, depressa, is totally distinct from anything placed in Gymnostylia by Brauer and Bergenstamm. It is a very large, robust, depressed, yellow species, 16 to $18 \mathrm{~mm}$. long, which I have not seen and am unable to place from the meager description (Macquart's description is compiled from Robineau's).

93. OXYAPORIA ORNATA Brauer and Bergenstamm

Gymnostylia ornata Schiner, Brauer and Bergenstamm, Denk. Wien. Akad. Wiss., vol. 56, 1889 , p. 128 , fig.; vol. 58, 1891, p. 374, desc.; vol. 60, 1893, p. 130.

One male, type of species, from Venezuela (Lindig, 1864). Schiner never described the species, hence it should be attributed to Brauer and Bergenstamm. They gave in 1891 a good but brief description. The species forms a distinct genus which has been named

\section{OXYAPORIA Townsend}

Oxyaporia Townsend, Insecutor Ins. Menst., vol. 6, 1918, p. 170; Revista Mus. Paulista, vol. 15, 1926, p. 273. Type designated, Gymnostylia ornata Schiner.

Elongated and slender, allied to Urodexodes but with parafacials hairy. Hypopleural bristles and post scutellum well developed. Front rather narrow, a little prominent, face moderately receding; eyes bare, rather obliquely placed so that the lower part is considerably anterior to back of head; cheek one-fourth the eye height.

\footnotetext{
9 Ins. Ins. Menst., vol. 9, 1921, p. 85.

${ }^{10}$ Vol. 2, 1835, p. 216.

11 Ins. Ins. Menst., rol. 4, p. 7.

19 Myodaires, 1830 , p. 322.
} 
Vibrissae at oral margin, facial ridges with a few hairs below; parafacials rather narrow, with a few distinct hairs all along near facial ridge. Third antennal joint elongate, moderately slender, three times the second, basal joints of arista short. Palpi normal, proboscis short. Thoracic chaetotaxy: acrostichal 3, 1; dorsocentral 3,4 ; humeral 3 ; posthumeral 1 ; presutural 2 (inner hairlike) ; notopleural 2 ; supraalar 3 ; intraalar 3 ; postalar 2 ; sternopleural 1,1 ; pteropleural small; scutellum with 3 lateral, only a minute hair or two at apex, one smaller discal pair.

Abdomen slender; one large median marginal on first and second segments, marginal row on third and fourth; second and third segments with 2 pairs discals, fourth thinly covered with bristles. Genitalia small, concealed. Sternites after the first concealed by overlapping of tergites. Legs long, claws and pulvilli large.

Wings long and narrow, first posterior cell open only a little before extreme apex, fourth vein with rounded curve; veins bare except a few hairs at base of third.

Type of genus. - Gymnostylia ornata Brauer and Bergenstamm.

\section{OXYAPORIA ORNATA Brauer and Bergenstamm}

Male.-Black, abdomen broadly yellow on sides. Head cinereous, palpi yellow. Thorax with large black median spot, slightly divided in the middle before the suture by a silver line which widens a little posteriorly, and concave behind on account of a silvery spot before scutellum; a wide silvery stripe begins at the humerus each side and narrows above the wing, reaching the corner of scutellum, the latter black with a little brownish reflection.

Abdomen with thin silvery tessellation, more distinct on sides, not forming crossbands except when viewed directly from behind; a median ventral black stripe on the tergites.

Legs black, elongated, the tarsi longer than the tibiae. Middle tibia with one bristle on outer front side, hind not at all ciliated; with one bristle on outer side below middle opposite one on inner side, and nearly opposite a flexor one.

Wings brown, hardly paler behind; third vein with about four hairs at base.

Length, $10.5 \mathrm{~mm}$.

Redescribed from the type in the Vienna Museum.

Not in the United States National Museum.

\section{URODEXODES CINGULATA Schiner}

Meigenia cingulata Schiser. Novara Ieeise, 1S68, p. :207.

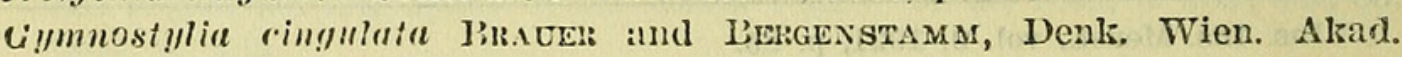
Wiss. vol. 58,1891 , 1. 4te.

The two type males are mentioned by Schiner, and agree with his description: Labeled, "Novara I. Brasilia." 
This species is in the National Museum, as I find the following specimens: Three males, Rio Charape, Peru, 3,700-4,500 feet, September 17 and December 12 and 15 (Townsend); one male and one female, Casahuiri, Peru, February 4 and 14 (Townsend); one male, Las Cascadas, Panama, March 3, 1909 (A. H. Jennings). I refer the species to the genus Urodexodes Townsend, described in Proceedings of the U. S. National Museum, ${ }^{13}$ with the single species charapensis, new, from Rio Charape, Peru. $U$. cingulata differs from charapensis, the genotype, in having yellow palpi, distinct but small ocellars, much more sharply defined silvery pollinose bands on the abdomen, and the wings hardly infuscated.

\section{LIXOPHAGA FAMELICA Wiedemann}

Tachina famelica Wiedemann, Auss. Zweifl., vol. 2, 1830, p. 331.

Gymnostylia famelica Brauer and Bergenstamm, Denk. Wien. Akad. Wiss., vol. 58, 1891, p. 405.

One male, considerably broken, "Brasilien, Coll. Winthem," agreeing with Wiedemann's description. It is a Lixophaga closely related to variabilis of North America.

Black with yellowish-gray pollen. Front 0.254 of head width; without orbitals. Third antennal joint three and one-half times the second; arista with basal joints short. Palpi yellow. Acrostichal, 3, 3; dorsocentral, 3, 3; sternopleural, 2, 1. Mesonotum with rather dense yellowish pollen on which are two pairs of shining black stripes, the outer broader and interrupted.

Abdomen rather narrow, with basal crossbands of yellowish pollen on second, third, and fourth segments, which occupy nearly half the length, are slightly interrupted at median line, and bear numerous small black dots from which the hairs arise. No discals even on the fourth segment, one pair median marginals on first and second segments, a marginal row on third and fourth. Third segment with no matted or clustered hair on ventral side. A trace of yellow ground color on silles of second segment.

Legs black. claws and pulvilli moderately elongate; middle tibia with one bristle on outer front side, hind not ciliated.

The species liardly differs from variabilis except in having fully the posterior half of abdominal segments 2,3 , and 4 shining, while in varialiiis the pollen cover's all except a narrow hind margin.

Not in United States National Museum.

Length, is $\mathrm{mm}$.

${ }^{13}$ Vol. :it, 1919, 1. :it:.

$55+1 \overline{2} \div$ 


\section{CHAETONA LONGISETA Wiedemann}

Dexia longiseta Wiedemann, Auss. Zweifl., vol. 2, 1830, p. 381.

Viviana citrina Bigot, Annales Soc. ent. France, 1889, p. 262.-Brauer, Sitzungsber. Kais. Mus., vol. 106, p. 7.

Chaetona longiseta VAN DER WULP, Biologia Dipt., vol. 2, 1891, p. 253, pl. 6, fig. 8.-Brauer and Bergenstamm, Denk. Wien. Akad. Wiss., vol. 50, 1891, p. 378 .

One female, "Brasilia," "longiseta Wd. coll. Winthem," and B. B. label. Undoubtedly the type, as the plumosity of the arista is matted together by treatment with a solution as Wiedemann says. A second specimen, a male, is erroneously labeled icterica, but does not agree with the type of that species; it is also from Brazil and in "coll. Winthem."

The genus Chaetona was established by Van der Wulp (see above) for this and another species. Coquillett designated longiseta as the genotype in his Type Species (1910, p. 521). A female in the National Museum from Caura Valley, Venezuela, was correctly identified by Townsend; and I have lately added a male, collected by me at La Providencia, Siquinala, Guatemala, April 16, 1926.

Van der Wulp's description and figure are very recognizable, but he shows the abdomen too broad near tip, and the profile shows the front too prominent and bulging. The exceptionally long arista with short, delicate plumosity is a very striking character.

\section{CHAETONA ICTERICA Wiedemann}

Tachina icterica Wiedemann, Auss. Zweifl., vol. 2, 1830, p. 321.

Chaetona icterica Braugr and Bergenstamm, Denk. Wien. Akad. Wiss., vol. 58, 1891, p. 378.-Townsend, Annals N. Y. Acad. Sci., vol. 7, 1892, p. 22.

Two males from the Winthem collection are so labeled, but not called types; both are from Brazil. One is Chaetona longiseta Wiedemann, but not the type specimen; this I eliminate from icterica. The other is a different species, and agrees with the description of icterica; undoubtedly the type.

Male.-Eyes bare; front narrow and rather prominent below, at narrowest 0.19 of headwidth by micrometer; a single pair of smallish verticals; ocellars small, proclinate; frontals about ten, the uppermost two reclinate, lowest at middle of second antennal joint (lower on one side than the other); parafrontals and parafacials yellowish pollinose, dull, the latter bare and as narrow as third antennal joint. Antennae black, slender, third joint nearly four times the second and slightly enlarged toward tip, arista slender except on basal fourth, less than twice as long as third antennal joint, with perhaps 
a slight pubescence in well-preserved specimens. Vibrissae slightly above oral margin, face not much receding, long and narrow, the ridges bare; palpi yellow, ordinary; cheek about one-third the eye height; proboscis short, fleshy.

Thorax considerably damaged; its ground color is black, the dorsum yellow. pollinose, on which stand out the narrow intermediate and broad interrupted lateral stripes in black, also a black basal semicircle on scutellum. Chaetotaxy, as far as can be made out: acrostichal (?) ; dorsocentral, 2, 3; humeral, 2 ; notopleural, 2 ; posthumeral, 1 ; presutural, 1 ; supraalar, 3 ; intraalar, 3 ; postalar, 2 ; scutellum with two lateral, one long apical; sternopleural, 2, 1; no pteropleural; hypopleural, 6 . Postscutellum well developed.

Abdomen yellow in ground color, tip of third segment and all but base of fourth black; bases of segments narrowly yellow-pollinose, in a very flat view the pollen grows much more extensive; first and second segments with one pair of median marginals, third and fourth with marginal row, no discals on any segment. Genital segments very small.

Legs black; claws and pulvilli a little elongated; middle tibia with a single bristle on outer front side; hind tibia not ciliated.

Wings quite uniformly infuscated, the veins on apical half bordered by a deeper shade, as Wiedemann says, fourth vein with oblique curve, then concave, the first posterior cell open not far before the apex; third vein with only two or three hairs at base.

Length, $8.6 \mathrm{~mm}$.

The species is not in the National Museum. It is not the type of any genus.

\section{NEOMINTHO MACILENTA Wiedemann}

Tachina macilenta Wiedemann, Auss. Zweifl., vol. 2, 1830, p. 305.

Neomintho macilenta Brader and Bergenstamm, Denk. Wien. Akad. Wiss., vol. 58, 1891, p. 339 ; vol. 60, 1893, p. 120.

Two males, "Brazilien," and "macilenta, Coll. Winthem." They agree with the descriptions except that the white pollen of the scutellum and the two slender black lines on the anterior part of the mesonotum are visible from behind, not in front. Undoubtedly the types. The genus was established by Brauer and Bergenstamm (1891, p. 339) for this species and two others. Townsend designated macilenta as type in $1916,{ }^{14}$ carrying out the apparent intention of the authors, who mentioned only this species in their 1893 paper (p. 120). Wiedemann's description is fairly recognizable, especially

14 Ins. Ins. Menst., vol. 4 , p. 8. 
when taken in connection with Brauer and Bergenstamm's. The latter mention the female, with flattened fore tarsi and smaller ocellars than the male; I do not have this sex.

Male.-Front at narrowest (vertex) 0.23 of head width. Front a little prominent, slightly shorter than face, which is receding. Head wider than high (48 to 37 ); vibrissae at oral margin; facial ridges bristly about half way; frontals descending to middle of second antennal joint; no orbitals; frontal stripe wide. Parafacials bare and silvery. One large pair of frontals reclinate; ocellars large, proclinate. Antennae long, third joint broadest in middle, three to four times the second; arista with basal joints short, slightly thickened for one-fifth its length. Palpi normal, yellow; proboscis fleshy, short. Back of head slightly bulging. Thorax somewhat damaged in both specimens, the disk nearly all black with broad white lateral border before wings. Pleurae almost silvery. Chaetotaxy: acrostichal, 2 anterior (none just before suture), posterior spoiled; dorsocentral, 3, 3; humeral, 3 ; posthumeral, 2 ; presutural, 1 large; notopleural, 2 ; supraalar, 3 (middle one large); intraalar, 3 (the front one minute); sternopleural, 3 in a small triangle rather far back; scutellum with 2 lateral (the posterior large) and one rather long, depressed apical pair; disk with upright bristly hairs and a few depressed ones behind. Post scutellum and hypopleurals well developed. Calypters moderately large, pure white. Abdomen narrow, shining black, the first segment nearly as long as the second; second and third with broad basal silvery band, including about half the segment above, less below; fourth segment wholly shining black. First segment with a pair of large strong median marginals; second the same; third with marginal row of same, but the median pair, as in the preceding segments, is not very close to hind margin; fourth segment with a marginal row placed as on third. The larger bristles of thorax and abdomen are flattened longitudinally at base, giving them a very stout appearance. There are no true discals on the abdomen.

Legs black, rather stout, front tarsi unusually so; all claws and pulvilli elongated. Middle tibia with three bristles on cuter front side, the intermediate largest; hind tibia with a few irregular bristles on outer side.

Wing noticeably brownish, more so along veins, tips rouncled, first vein hairy on its middle third, third vein hairy almost to small cross vein; bend of fourth vein oblique. slightly rounded: first posterior cell open in margin rather far before apex; third vein undulating beyond small cross vein, widening the first posterior cell near its middle. 
The genus differs from Phorocera in having the head more rounded, first vein hairy, and abdomen narrow. The female probably has a piercer, as Brauer and Bergenstamm say the venter is "stufig" (in steps).

The genitalia (fig. 1) are much like those of Phorocera (Euphorocera, Neophorocera) claripennis Macquart, of the United States; the united inner forceps form a convex disk basally with a slight, shining median ridge, the apex drawn out into a slender process slightly curved up; the outer forceps are reduced to flat plates. Both pairs brown in color. The fourth abdominal segment is greatly shortened below, the sternite small and almost invisible.

Not in the National Museum.

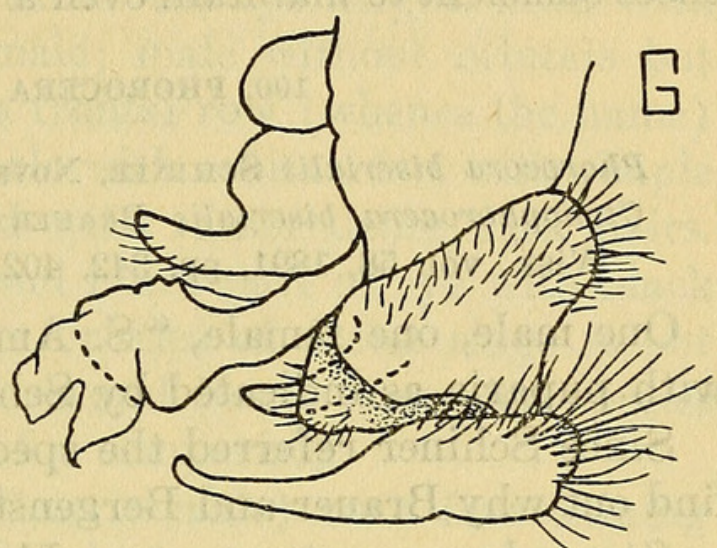

Fig. 1.-NeOMintho maCiLenta WimdemanN

\section{PHOROCERA HEROS Schiner}

Phorocera heros ScHINer, Novara Reise, 1868, p. 325.

Neomintho heros Brauer and Bergenstamm, Denk. Wien. Akad. Wiss., vol. 58, 1891, p. 339.

Phorocera coccyx ALdRICH and WeBBER, Proc. U. S. Nat. Mus., vol. 63, art. 17, 1924, p. 64 .

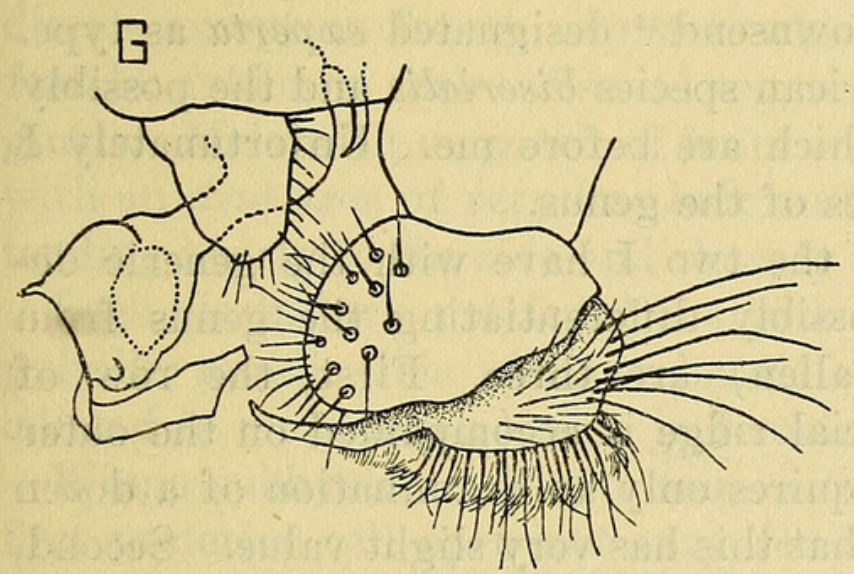

Fig. 2.-Phorocera heros Schiner

Two males, "Brasilien," one is "Coll. Winthem" and the other is apparently from the same lot.

I have spread the genitalia of these males and find them to be of the same species described as Phorocera coccyx by Aldrich and Webber in 1924 from Virginia, New York, and Indiana. Specimens received later are from Maryland, Oklahoma, and Cordoba, Mexico. Since Schiner mentioned only a female in the original description, it might be thought that neither of the Brazilian specimens received from the Vienna Museum could be the type. However, it seems clear that Schiner made a mistake regarding the sex. $\mathrm{He}$ gives the length as $15 \mathrm{~mm}$., agreeing with these males, while in this species the female has a shorter abdomen, our single specimen of this sex measuring only $9 \mathrm{~mm}$. The description of coccyx is accessible and need not be repeated, but I add a figure of the unique genitalia 
(fig. 2, drawn by my colleague, C. T. Greene). I see only two slight points of difference between our northern males and the Brasilian ones-the latter have two small bristles outside the lower ones in the frontal row, as mentioned by Schiner, and they also have a somewhat narrower and more sharply limited basal pollinose crossband on the second and third abdominal segments. I do not consider these differences suficient to maintain even a varietal standing for coccyx.

\section{PHOROCERA BISERIALIS Schiner}

Phorocera biserialis SchrneR, Novara Reise, 1868, p. 326.

Ctenophorocera biserialis Brauer and Bergenstamm, Denk. Wien. Akad. Wiss., vol. 58, 1891, pp. 342, 402.

One male, one female, "S. Amerika" and "Rio de Janei", both with puparia as indicated by Schiner.

Since Schiner referred the species to Phorocera, it is necessary to find out why Brauer and Bergenstamm placed it in a different genus.

Ctenophorocera was proposed by Brauer and Bergenstamm in 1891, and four species were placed in it-Tachina experta Wiedemann, from Cape of Good Hope; Phorocera biserialis Schiner from Brazil; Tachina munda Wiedemann, from Tranquebar; and blepharipus, new species, from Cape of Good Hope or Brazil. In 1893 (p. 84) they removed munda Wiedemann to Achaetoneura, remarking that the eyes were almost bare. In the same year in the keys they placed the genus Ctenophorocera, on page 119, in the Group Phorocera and ort page 121, in Group Blepharipoda, both times referring directly to experta as if it were type. Townsend ${ }^{15}$ designated experta as type.

I asked to see only the American species biserialis and the possibly American one blepharipus, which are before me. Unfortunately I did not ask for the type species of the genus.

I have, however, compared the two I have with the generic description. The characters possibly differentiating the genus from Phorocera (type assimilis Fallen) are three. First, the row of bristles extending up each facial ridge is accompanied on the outer side by a row of hairs. It requires only an examination of a dozen or so of related species to see that this has very slight value. Second, the length of the head at vibrissae is almost equal to that at antennae; in other words the face is hardly receding. This is true of blepharipus but certainly not of biseriatis. The American genus Murdockiana might be considered here, but it has the opistoma strongly jutting forward between the vibrissae, unlike blepharipus. The third character is the ciliation of the hind tibiae, which is present in both of the species before me. This is a character which is best developed in males, runs through all possible degrees, and its

${ }^{16}$ Ins. Ins. Menst., vol, 4, 1919, p. 7. 
validity, never high in this group, depends on the absence of connecting forms in the particular small series under consideration. Not having the genotype of $C$ tenophorocera at hand, I can express no positive opinion of the genus, but I would put biserialis back in Phorocera, where Schiner described it.

Front at narrowest 0.23 of the head width in male, 1).27 in female at vertex. Eyes densely hairy, cheek 0.3 the eye height. head with yellow pollen in male, gray in female; male without orbitals but with a few extra bristles outside the frontal row (whence the name) opposite the antennal insertion; female with orbital. but with simple frontal row; palpi yellow, obscured with rather dense dark hairs. Cheek and a considerable space behind lower part of eye with black hair. The row of hairs outside the bristles of facial ridge is but slightly developed, no more than in several North American species of related genera which I examined for comparison.

Mesonotum gray (tinged with yellow in male) with four shining black stripes. Chaetotaxy: acrostichal, 3, 3; dorsocentral, 3, 3; humeral, 4 ; posthumeral, 2 ; presutural, 2 ; notopleural, 2 ; supraalar, 3 ; intraalar, 3 ; postalar, 3 (1 large between 2 small) ; sternopleural, 1,1 (2, 1 in male, the lower small) ; pteropleural, 0 ; scutellum with 3 lateral, 1 small apical (broken off) and 1 discal. Scutellum dark in ground color with only trace of lighter at tip, densely gray pollinose with a darker spot on disk beyond middle. Calypters yellowishwhite. Abdomen black, densely gray pollinose, tessellated, more yellowish in male and with indistinct reddish ground color at sides; no. discals except on fourth segment, which has dense yellow pollen in female, golden in male. Second segment with one pair median marginals. Male with no patch of hairs on venter of third segment, but with an oval area of very fine hair on the fourth segment below, extending nearly to the side and sharply differentiated there.

Legs black, tarsi not long, but with slightly elongated claws and pulvilli; middle tibia with one bristle on outer front side; hind tibia ciliated in male, much less so in female.

Wings subhyaline; fourth vein with rounded rectangular bend; first posterior cell open not very far before apex; third vein with 2-3 hairs at base, other veins bare.

Length, $8 \mathrm{~mm}$.

Not in National Museum.

101. PHOROCERA CAERULEA Jaennicke

Phorocera caerulea JAENNICKe, Neue Exot. Dipt., 1867, p. 382.

Ctenophorocera blepharipus Brauer and Bergenstamm, Denk. Wien. Akad. Wiss., vol. 58, 1891, pp. 342, 402.

The locality as given in the original description was left in uncertainty between Cape of Good Hope and Brazil, hence I asked to see 
the type. It is a male labeled "caffra. Coll. Winthem," and " 89 " on a red tag; also a large blue name label in Doctor Villeneuve's writing, upon which after the name he has written "(caerulea Jaenn. teste Brauer)". As Jaennicke's species was from Abyssinia, I conclude that blepharipus is African, and may be dropped from the American list.

\section{PAMMAERUS LEPTOTRICHOPUS Brauer and Bergenstamm}

Sisyropa leptotrichopa Brauer and Bergenstamm, Denk. Wien. Akad. Wiss., vol. 58, 1891, p. 347.

Two males on same pin, from "Brasilien" and bearing the Brauer and Bergenstamm label. Undoubtedly the types, although taken for females by the describers on account of the presence of orbital bristles. I designate the species as the type of the following new genus.

\section{PAMMAERUS, new genus}

Allied to Doryphorophaga and Muscinothelaira. Eyes hairy; front broad in male with two pairs of orbitals; ocellar bristles of ordinary size, located rather far forward, so the anterior ocellus is exactly between them; ocellar triangle large; parafacials rather wide, very bright silvery pollinose; third antennal joint slender, four times the second, with long, thin arista, its basal joints short. Frontal bristles far apart (upper two pairs probably reclinate but missing), the lowest at middle of second antennal joint. Front not prominent, face receding; facial ridges feebly bristled almost to middle.

Palpi normal, proboscis short, cheek one-eighth the eye height. Thoracic chaetotaxy : acrostichal, 3,3 ; dorsocentral, 3,4 ; humeral, 4; posthumeral, 2; presutural, 2 (the inner minute); notopleural, 2; supraalar, 3 (stout, flattened) ; intraalar, 3 ; postalar, 2 ; sternopleural, 2, 1; pteropleural minute; scutellum with 3 lateral, one small decussate semierect apical, and one small discal.

Abdomen without discals on second, third, and fourth segments. One small pair median marginals on first segment, one large on second, a row on third and fourth. Third segment on ventral side with patch of dense, short hairs. Genitalia small.

Tarsi with minute claws and bristles; middle tibia with a single bristle on outer front side; hind tibia ciliated, with one bristle below middle of row in one specimen.

Wings of ordinary structure, first posterior cell open before apex, third vein with 5-8 coarse hairs at base.

Type of genus.-Sisyropa leptotrichopa Brauer and Bergenstamm. 


\section{PAMMAERUS LEPTOTRICHOPUS, Brauer and Bergenstamm}

Male.-Front broad, 0.35 of the head width, with two large orbital bristles on each side. The ground color of the front is black, heavily overlaid with yellow pollen. The median stripe is brown, almost as wide as either parafrontal. Verticals one large and one small; frontals about six, the upper two pairs represented only by large scars, probably reclinate, the next ones much smaller, decussate, one pair large just at the root of the antennae, and one pair below these. The parafrontals are rather densely covered with short black hairs, which below the upper orbital are proclinate, but above it are reclinate, while near the median stripe they are directed toward the middle line. This peculiar arrangement of hairs $I$ have never seen in any other species, and it is rather noticeable. Parafacial and poste rior orbit, except the upper part, bright silvery pollinose; the former gradually narrowing to almost the level of the vibrissae, where it is about as wide as the third antennal joint. Antennae black, rather brownish at base; third joint decidedly slender and about three and one-half times as long as the second. Arista bare, very thin on the apical half, the basal third slightly thickened. Facial ridges with hairs and small bristles extending more than one-third of the way to the root of the antenna. Cheek one-sixth the eye height; palpi yellow; proboscis small; back of head flat with usual ruff of white hairs not very well developed, the lower part of the head having many black hairs extending from the cheek half-way up the orbit. Ocellar bristles small, proclinate.

Thorax and abdomen wholly black in ground color, the former with four subshining black stripes on gray pollen. The scutellum with yellowish pollen, black at base and a very slight reddish tinge in the ground color around the apex. Thoracic chaetotaxy: acrostichal, 3, 3; dorsocentral, 3, 4; humeral, 4; posthumeral, 3 (including one interhumeral) ; presutural, 2 ; notopleural, 2 ; supraalar, 3 ; intraalar, 3 ; postalar, 2 ; sternopleural, 2,1 ; pteropleural, 0 ; scutellum with 3 lateral and a small decussate pair of apicals.

Abdomen broadly pollinose on the last three segments, but not in very good condition to describe; the first segment has a very small pair of median marginals; the second a large pair; the third a marginal row of eight; the fourth a smaller marginal row of the same number. There are no discals on any segment; the fourth segment is densely pollinose on its whole upper surface as far as the row of bristles. Genitalia small; legs black; the knees narrowly reddish; all the claws and pulvilli small; middle tibia with one large bristle on outer front side; hind tibia with an even row of cilia and one larger bristle near the middle. 
Wings hyaline; bend of fourth vein forming a rounded right angle, the cell open considerably before the apex; third vein with five to eight rather strong bristles at base; the costal segment between the auxiliary and the first vein rather longer than usual, about two-thirds of the following one.

Length, $11 \mathrm{~mm}$.

Not in the National Museum.

\section{PARAPORIA QUADRIMACULATA Macquart}

Aporia quadrimaculata Macquart, Dipt. Exot. Suppl., pt. 1, 1846, p. 296.Schiner, Novara Reise, 1868 , p. 319.-Brauer and Bergenstamm, Denk. Wien. Akad. Wiss., vol. 56, 1889, p. 130, fig. 222.

- Two specimens from Vienna are male and female. They are labeled "Lindig 1864 Venezuela." They agree with Macquart and Schiner accounts, but are not types. The species is the type of Aporia Macquart, but that name was preoccupied. Townsend proposed to change it to Neaporia ${ }^{16}$; as this was later discovered to be preoccupied also, he changed it to Paraporia. ${ }^{17}$ The species is not represented in the National Museum.

The specimens are not of the same species as those in the National Museum determined as quadrimaculata and so accepted by me. ${ }^{18}$ These latter (two males) are much more like Uramyia, having an equally long but somewhat broader abdomen; they have on the second and third abdominal segments a large dark triangle with its truncated apex touching the preceding segment, leaving a cinerous spot on each side at base; these spots are not widely separated, and fade posteriorly, the rest of the dorsum of the segment being more or less reddish.

The true quadrimaculata, agreeing with Macquart's description and figure, is the species from Vienna; it has a much wider and shorter abdomen, velvet black in color, the two pairs of spots farther apart, smaller and much more sharply outlined. It is this form which is the genotype of Paraporia; there is no doubt of this, as Townsend proposed Neaporia long before he had seen a specimen, and it merely replaced Aporia, to be itself replaced by Paraporia. Neither genus was based on the specimens now in the National Museum. In this sense I think the genus Paraporia is a valid one, although in 1921, supposing the specimens in the National Museum to be of the type species, I placed it as a synonym of Uramyia.

The species which was called quadrimaculata by me in 1921 I would now call Uramyia acuminata Van der Wulp, which I erroneously placed as a synonym.

${ }^{16}$ Muscoid Flies, 1908, p. 67.

17 Ent. Soc. Wash., vol. 14, 1912, p. 48.

${ }^{18}$ Ins. Ins. Menst., vol. 9, 1921, p. 85. 
Length, $16 \mathrm{~mm}$., the same in both.

Macquart's figure of quadrimaculata shows the arista plumose, whereas it is merely pubescent on the basal half, bare apically; his text, however, calls it tomentose.

\section{EUANTHA LITURATA Olivier}

Ocyptera liturata OLIVIER, Encycl. Methodique, Hist. Nat., vol. 8, p. 423.

Dexia dives WredemanN, Auss. Zweifl., vol. 2, 1830, p. 377.

Sericocera pictipennis MacquaRT, Dipt. Exot., pt. 2 (3), 1843, p. 67, pl. 7. fig. 5 .

Euantha dives VAN DER WULP, Tijdsch. v. Ent., vol. 28, 1885, p. 198 ; Biologia Dipt., vol. 2, 1891, p. 248.-Brauer and Bergenstamm, Denk. Wien. Akad. Wiss., vol. 56, 1889, p. 137 ; vol. 60, 1893, p. 128.-Townsend, Ann. Mag. Nat. Hist., vol. 19, 1897, p. 34.

Euantha pulchra VAN DER WULP, Biologia, Dipt., vol. 2, 1891, p. 249.

Euantha liturata Coquillett, Revis. Tachin., 1897, p. 86.-HowaRd, Ins. Book, 1902, p. 162.-JoHnson, Psyche, vol. 19, 1912, p. 103.

One male, one female, both labeled "S. America, Coll. Winthem" and "dives Wd. Type BB." They agree with the description and are old specimens, but in good condition; presumably they are from the same period if not actually types. They agree with Van der Wulp's figure in Biologia except that he has the vibrissae too high up. There is a distinct costal spine, as noted by Townsend. The National Museum has ten specimens of both sexes, from Guatemala (Aldrich), Vera Cruz (Townsend), Florida, and Colorado, the last identified by Brauer and Bergenstamm. Coquillett made dives a synonym of liturata Olivier, which I believe on examining the original description is no doubt correct.

The female has the front shining, precisely as Van der Wulp indicates for his species pulchra; apparently he mistook some males of dives as females, as he says in this species the female does not have orbitals as it does in pulchra. It therefore seems certain that pulchra is a synonym. Dives is the genotype of Euantha.

\section{EUANTHA AUCTA Wiedemann}

Dexia aucta Wiedemann, Auss. Zweifl., vol. 2, 1830, p. 377.

Euantha aucta Brauer and Bergenstamm, Denk. Wien. Akad. Wiss., vol. 58,1891 , p. 405 .

One female, labeled "Brazilia," "Coll. Winthem," and "Euantha aucta Wd." It agrees precisely with the description.

The species differs from liturata in having no yellow in wings, general darker color, and legs black except at bases of femora. The front of the female is wholly pollinose except a small area including the bases of the orbital bristles. As Wiedemann says, the pollen of the bands on the base of second and third abdominal segments does not extend down the sides. The National Museum has two females 
from San Bernardino, Paraguay (Fiebrig), and one male from Yahuarmayo, Peru (Townsend). In the male the two abdominal bands extend down the sides to the margins of the tergites.

I add a third species with key to all three.

KDY TO SPECIES OF EUANTHA

1. Fourth vein with long appendage at bend; pollinose bands of second and third abdominal segments not interrupted in middle

Fourth vein without appendage at bend or with a mere trace of one; abdominal pollinose bands interrupted in middle. interrupta, new species.

2. Wing blackish without yellow region; male with black femora and abdomen. Female with abdominal bands not extending down the sides.

aucta Wiedemann.

Wing blackish apically, broadly yellow in middle; male with yellow femora and most of second and third abdominal segments reddish; female with abdominal bands extending down the sides (dives Wiedemann).

liturata Olivier.

\section{EUANTHA INTERRUPTA, new species}

The male is similar in appearance to the two known species, but the yellow blotch in the wing is more squarely cut off just beyond the small cross vein, and the abdomen does not show the red ground color which is prominent in liturata. The abdominal bands are narrowly but distinctly interrupted in the middle line.

The female has quite black wings, with the discal cell nearly to its tip whitish, strongly contrasting. The abdominal bands are narrow and widely interrupted. It is much easier to pick the females as a distinct species than the males. The front of the female is indistinctly shining or very thinly pollinose along the middle stripe.

Legs black in both sexes.

Length of male, 11.2 to $13.6 \mathrm{~mm}$.; of females, 9.2 to $11.8 \mathrm{~mm}$.

Described from four males and three females. Collected at Higuito, San Mateo, Costa Rico, by Pablo Schild. One specimen is dated August 6, 1914.

Type.-Male, Cat. No. 40395, U.S.N.M.

106. PSEUDODEXIA EQUES Wiedemann

Dexia eques Wiedemann, Auss. Zweifl., viol. 2, 1830, p. 378.

Pseudodexia eques Brauer and Bergenstamm, Denk. Wien. Akad. Wiss., vol. 58, 1891, pp. 372, 378; vol. 60, 1893, p. 131.

One male, labeled "Bahia" "eques Wd. Coll. Winthem." Uncloubtedly type of the species eques, which is the genotype of Pseudodexia. Agrees exactly with Wiedemann's description; the specimen is characterized by a very peculiar wing, reproduced in Figure 3, which has been carefully drawn by C. T. Greene. The apical half of the wing is remarkably elongated, and there is a marked although 
slight concavity in the costa before the extreme apex; the third vein has only one bristle at base above and below. The species is not represented in the National Museum, although Dr. C. H. T. Townsend had identified a closely related form with less elongated wing as "eques subspecies with golden squamae." Mr. Malloch had named the same species Morinia longitarsus Wulp, but I do not think it fits the description very well. The color of the thorax is sharply divided at the suture, being golden in front and dark brown behind. Thè slender abdomen is subshining black, with silver fasciae at base of second and third segments, narrower across the dorsum but broad laterally; the fourth segment is wholly silvery except a narrow black tip which bears a considerable tuft of bristles. There are no discals on the second and third segments. The first segment is uncommonly long, exceeding the second, but has no median marginal bristles; the second has one pair and the third a row of about six; the fourth has no discal bristles.

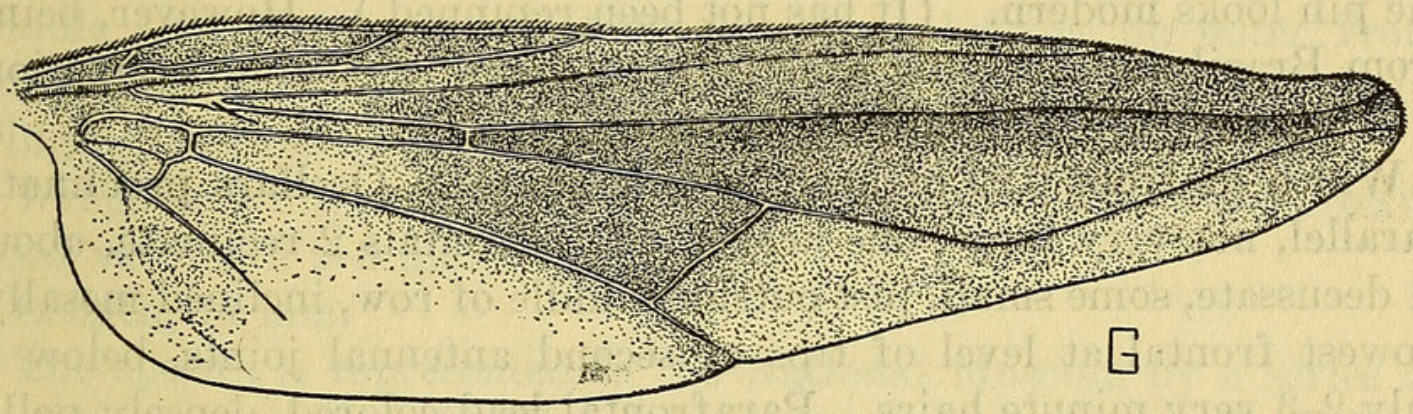

Fig. 3.-Pseddodexia eques Wimdemann

The head is almost circular when viewed from in front and the antennæ attached slightly below the level of the middle of the eye, the third joint slender, over three times the second; arista rather short-plumose almost to its tip. Front golden pollinose almost to the antennae, at narrowest hardly wider than ocellar triangle, the frontal bristles beginning at the narrowest place and barely reaching the base of the antennae; parafacials narrow, silvery; vibrissae at margin of mouth, a few small bristles extending up almost halfway on the facial ridges; face rather flat and considerably receding; palpi normal, yellow; proboscis small, fleshy.

Thoracic chaetotaxy so badly damaged that it can not be made out. Hind calypters very large, postscutellum and hypopleurals present. Legs black; middle tibia with two bristles on the outer front side; hind tibia with a partial row of quite small bristles on the outer hind side, one below the middle a little larger, standing directly opposite to one of equal size on the inner hind side. Claws and pulvilli elongate. 
Length of body, $8.4 \mathrm{~mm}$; of wing, $10 \mathrm{~mm}$.

Undoubtedly the female would have a normal or nearly normal wing.

\section{BLEPHARIPEZA LEUCOPHRYS Wiedemann}

Tachina leucophrys Wiedemann, Auss. Zweifl., vol. 2, 1830, p. 308.

Blepharipeza rufipalpis Macquart, Dipt. Exot., pt. 2 (3), 1843, p. 211.VAN DER WULP, Tijdsch. v. Ent., vol. 26, 1883, p. 25.

Tachina latifrons and nigrorufa WALKER, Dipt. Saund., 1852, p. 284.

Blepharipeza leucophrys ScHINeR, Novara Reise, 1868, p. 336.-WILliston, Trans. Amer. Ent. Soc., vol. 13, 1886, p. 304.-Giglio-Tos, Ditt. del Mess., pt. 3, 1894, p. 28.-Brauer and Bergenstamm, Denk. Wien. Akad. Wiss, vol. 60, 1893, p. 120.-CoquILLETT, Revis. Tachin., 1897, p. 124.

Belvosia leucophrys VAN DER WULP, Biologia, Dipt., vol. 2, 1888, p. 30.

One male, labeled "Winthem Coll."; has three labels of "leucophrys," one very old. The word "type" does not occur on any. The specimen is in fine preservation and one would hardly think it could have ever been seen by Wiedemann; it does not look old enough and the pin looks modern. (It has not been repinned.) However, being from Brazil and agreeing exactly with the Wiedemann description, it is undoubtedly authentically determined.

Width of front 0.25 of head by micrometer. Ocellars proclinate, parallel, not very large, one broken off. Frontals 2 reclinate, about 11 decussate, some small, just outside middle of row, inclined mesally. Lowest frontal at level of tips of second antennal joints, below it only 2-3 very minute hairs. Parafrontal lead colored, densely pollinose; parafacial pure white, not silvery; transverse impression and lower posterior orbit the same; cheek with black hairs nearly to eye and covered with very dense long white pollen, the little white scales suberect and distinct under high power. Antennae black, the third joint a little more than twice the second, moderately slender, not reaching vibrissae; arista rather long, evenly tapering, basal joint short. Palpi yellow at least on apical half. Back of head white pollinose and pilose with one row black above and $2-3$ below. One pair of verticals, not decussate, reclinate. Facial ridges with coarse erect bristles not quite to the level of lowest frontal.

Thorax thinly slaty or plumbeous above to scutellum, the latter brown. A fine brown line each side halfway between acrostichal and dorsocentral, also an interrupted short line outside dorsocentral. Chaetotaxy: humeral, 3 ; posthumeral, 2 ; acrostichal, 3 , 3: dorsocentral, 3, 4; notopleural, 2 (hairy around them); supraalar, 3; intraalar, 3 ; postalar, 2 ; scutellum with 4 long marginals each side curved down, one widely separated discal also curved down; disk spiny, less so in front, one pair slanting spines almost apical in position. 
Sternopleural, 2, 1, the lower anterior small; pteropleura with dense tuft and one small bristle; hypopleural, 8. Can not see under calypter, which is brown but not so dark as scutellum and abdomen.

Abdomen uniformly brown, subshining, first segment with row of small spines along middle of hind edge, hardly noticeable; second segment with about a dozen small erect blunt spines along the middle region and four larger on hind edge ( 2 pairs) a wide space between these and the lateral one; third segment with a few very irregular discal erect spines, longer than those on second and confined to posterior half of segment; hind edge with row of stout, blunt spines about as long as the segment. The hair of the segment is more dense and erect at each side behind middle but does not form a matted patch below, though it is dense there; fourth segment with erect bristles all over, those on disk more spiny, at apex with only small bristles; genital segments brown.

Prosternum with soft dark hair, a deep depression in its middle.

Legs black, pulvilli yellowish-brown, rather long on all tarsi; middle tibia with row of about four long bristles on outer front side; hind tibia with characteristic large row of flattened hairs fringing outer hind side.

Wings brownish, especially at base; epaulet and subepaulet brown; third vein with 2-3 hairs.

Length, $14 \mathrm{~mm}$.

The species is represented in the National Museum by a series of specimens, collected in Panama, Guatemala, and northward to Massachusetts.

108. SPALLANZANIA AMERICANA Schiner

Cnephalia americana ScHINer, Novara Reise, 1868, p. 327.

One female "Novara R. Chili," the undoubted type of Schiner, agreeing with the description and having the abdomen damaged in the same way. This is a true Spallanzania. It is well described by Schiner and I add only a few items.

The vertex is 0.41 of the head width, the eyes diverging only a little and slightly converging again at the lowest part. The ocellar bristles are broken off but without much doubt they were reclinate. The bristles of the front are also mostly broken off, but the scars show two or three rows, the outer quite irregular; the parafacial has a row of about five rather strong bristles nearly in the middle, the space between them and the orbit bearing coarse hairs, but between them and the facial ridges the surface is bare. The pollen of the head is silvery when viewed from in front, with irregular blackish pollen along the orbits above; when viewed from above, however, the parafrontals appear black almost to the level of the antennae. 
In an oblique side view a silver streak passes from the antennae to the orbit bordered above and below by blackish streaks; the antennae and palpi are black, the facial depression is rather shallow and the ridges have only four or five small bristles above the vibrissae. The length of the head is the same at the antennae and at the vibrissae (45 units), not including the epistoma which juts farther forward; the height of the head is 55 units. The second antennal joint is 11 units long and the third 16.

The thorax is very distinctly striped, the abdomen mostly shining black with distinct median pollinose vittae; the apical third of the fourth segment is orange red in color, more conspicuous at the extreme tip beyond the small bristles. There are four sternopleurals on one side, three on the other.

Length, $10 \mathrm{~mm}$.

Not in the National Museum.

\section{BELVOSIA ESURIENS Fabricius}

Musca esuriens FABricius, Syst. Antl., 1805, p. 301.

Tachina esuriens WIEDEMANN, Auss. Zweifl., vol. 2, 1830, p. 309.

Willistonia esuriens Brauer and Bergenstamm, Denk. Wien. Akad. Wiss., vol. 56, 1889, p. 97 ; vol. 58, 1891, pp. 349,403 ; vol. 60, 1893, pp. 123, 204.

Two males from Brazil, both "Coll. Winthem." and bearing the small, square red tag without writing, which Brauer says indicates Wiedemann's original specimens. One is labeled "esuriens Wd. (Fab.? )" on a very old label; the other has a B. B. label "Willistonia esuriens Wd."

Neither of these can be a Fabrician type, as the Winthem Collection contained none. The two specimens unfortunately are not of the same species, and it becomes a serious question whether either can be regarded as an undoubted esuriens. Wiedemann apparently saw the Fabrician type when he redescribed the species; his first specimen mentioned above fits his own and the Fabrician description better than the second, and in spite of the question mark I think it must be regarded as the authentic specimen. It has the two whitish abdominal crossbands as mentioned by Fabricius, and the one on the third segment is obviously interrupted as mentioned by Wiedemann. I therefore describe this specimen as the true esuriens, since there are probably no Fabrician specimens in existence.

Male (Wiedemann erroneously calls it a female). Front at vertex 0.31 of head width; the eye rather broadly rounded above so that the narrow part continues a little forward from the ocelli then rapidly widening; parafrontal with three very irregular rows of bristles inclined toward the center, the pollen gray becoming very thin toward the vertex. Face and parafacials pure white, the latter somewhat silvery; hairs below the lowest frontals black, in certain 
lights two or three may have a pale reflection; cheek white pollinose and with white hairs among which three or four are black. Cheek two-fifths of the eye.height. Vibrissae almost the length of the second antennal joint above the oral margin; facial ridges with seven or eight strong bristles, the row almost reaching level of arista; third antennal joint three times the second, which is brown in color; palpi yellow. Thorax black with thin gray pollen anteriorly; the scutellum subshining with a brown tinge. Calypters decidedly brown. Sternopleurals 4 .

Abdomen black, subshining; second segment with narrow basal band of light yellow pollen; third segment with a distinctly interrupted band of almost white pollen covering a little more than the basal half and extending on the venter; fourth segment decidedly pollinose except the tip where the bristles arise which is black; there is also a slender black median line scarcely interrupting the pale pollen. First and second segments with one pair of median marginals; third and fourth with a marginal row.

Legs black, the front claws and pulvilli elongated, the latter slightly longer than the last two tarsal joints. Hind tibia with several rather large suberect bristles on the outer side on the upper half, the lower half with uniform row of smaller bristles. All these bristles stand along the outer side of some more depressed hairlike ones.

Wings rather light brown in color, narrow toward apex, bend of fourth vein rectangular but rounded, a little nearer the margin of the wing than usual; base of third vein with three or four hairs.

Length, $11.5 \mathrm{~mm}$.

Four specimens of this species, a male and three females, have been received from the American Museum of Natural History; they were collected at Chapada, Brazil, by H. H. Smith. The male has a longer third antennal joint and a narrower band on the third abdominal segment than the Vienna specimen, but the females are like the latter.

The second specimen received under the name of esuriens will be included as a paratype of a new species, in a revision of the genus soon to appear.

110. BELVOSIA POTENS Wiedemann

Tachina potens Wiedemann, Auss. Zweifl., vol. 2, 1830, p. 299.

Willistonia potens Brauer and Bergenstamm, Denk. Wien. Akad. Wiss., vol. 58, 1891, p. 403.

One male, Rio Janeiro, "Coll. Winthem," and an old label "Tachina potens Wd." Wiedemann described the head of this specimen so well that it must be the type, although he strangely neglected to mention the striking marks of pollen on the abdomen.

55415-27-3 
Front, at vertex, 0.34 of the head width, the narrowest point being directly across the anterior ocellus; the entire front of the head and the posterior orbits are silvery pollinose, the frontal stripe, however, brown. In this specimen the reddish ground color of the parafacials, facial ridges, and cheeks shows through to a noticeable extent and the suture is distinctly bordered with a darker tinge to its lowest end. Frontal bristles in a single row, the hairs below the lowest are black, as are also the hairs of the cheek. Face considerably depressed in the middle, the vibrissae about the length of the second antennal joint above the oral margin; facial ridges with well-developed bristles up to a point above the middle of the third antennal joint. Antennae black, second joint more dark brown, with a tinge of red at the junction with the third, which is three times as long as the second and a little tapering. Palpi dark yellow, cheek almost half the eye height, beard white.

Thorax brownish black with usual thin pollen more distinct in front. Scutellum brown, with four pairs of bristles, the median pair of the same appearance as the others. The disk has about a dozen depressed small bristles. Calypters brown. Sternopleurals 4 on one side, 5 on the other.

Abdomen black, with faint reddish tinge at the sides; third segment with only a very narrow basal interrupted, white, pollinose, crossband, hardly more than a line; fourth segment with dense pale yellow pollen, the apical third black.

Legs black, front pulvilli slightly longer than last two tarsal joints; hind tibia on outer side with a row of small, suberect bristles mixed with a few hairs not so bushy in appearance as in many species.

Wing brown throughout, narrow at apex, bend of fourth vein rectangular and rounded, its distance from the hind margin less than half of that to the large cross vein; third vein with two bristles.

Genitalia smaller than in most of the species, the inner forceps black, closely pressed together near tip and bent forward almost with an angle; outer forceps hardly so long, dark yellow in color, flat and bluntly rounded at tip.

Length, $10 \mathrm{~mm}$.

Represented in the National Museum by two females from Ypiranga, Sao Paulo, Brazil ("Fonseca leg."). In these the single row of frontals is as characteristic as in the male, and they have four proclinate orbitals in a row, rather far from the eye. The pollen on the parafrontal becomes very thin or almost absent on an oval area that does not include the frontals but touches the eye near the vertex; this area is more or less subshining black, but less in one specimen than the other. The vertex is 0.40 of the head width, the same in both. 
SUMMARY OF CHANGES OF NOMENCLATURE PROPOSED

NEW GENUS

Pammaerus for Gymnostylia leptotrichopa Brauer and Bergenstamm.

NEW SPECIES

Euantha interrupta Aldrich, from Costa Rica.

NEW SYNONOMY

Camptops Aldrich equals Pachygraphia Brauer and Bergenstamm. Hystriciopsis Townsend equals Hystricia Macquart.

Sisyropa Brauer and Bergenstamm equals Zenillia Robineau-Desvoidy.

Gymnostylia Macquart equals Macromya Robineau-Desvoidy.

Phorocera coccyx Aldrich and Webber equals Phorocera heros Schiner.

PREVIOUS SYNONOMY CORRECTED

Paraporia Townsend is not a synonym of Uramyia Robineau-Desvoidy.

NEW COMBINATIONS

Zenillia thermophila Wiedmann for Tachina thermophila Wiedemann.

Zenillia rufiventris Brauer and Bergenstamm for Sisyropa rufiventris Brauer and Bergenstamm.

Zenillia proserpina Brauer and Bergenstamm for Sisyropa proserpina Brauer and Bergenstamm.

Urodexodes cingulata Schiner for Gymnostylia cingulata Schiner.

Lixophaga fametica Wiedemann for Tachina famelica Wiedemann. 


\section{$2 \mathrm{BHL}$ Biodiversity Heritage Library}

1927. "Redescription of types of American Muscoid flies in the collection of the Vienna Natural History Museum, with incidental notes." Proceedings of the United States National Museum 72(2703), 1-35.

View This Item Online: https://www.biodiversitylibrary.org/item/100797

Permalink: https://www.biodiversitylibrary.org/partpdf/41023

\section{Holding Institution}

Smithsonian Libraries

\section{Sponsored by}

Biodiversity Heritage Library

\section{Copyright \& Reuse}

Copyright Status: Public domain. The BHL considers that this work is no longer under copyright protection.

This document was created from content at the Biodiversity Heritage Library, the world's largest open access digital library for biodiversity literature and archives. Visit BHL at https://www.biodiversitylibrary.org. 